\title{
Acid and Enzymatic Hydrolysis of the Residue from Castor Bean (Ricinus communis L.) Oil Extraction for Ethanol Production: Detoxification and Biodiesel Process Integration
}

\author{
Walber C. Melo, ${ }^{a}$ Alexandre S. dos Santos, ${ }^{b}$ Lídia Maria M. Santa Anna ${ }^{c}$ and Nei Pereira Jr.*a
}

${ }^{a}$ Departamento de Engenharia Bioquímica, Universidade Federal do Rio de Janeiro, CP 68542, 21949-900 Rio de Janeiro-RJ, Brazil

${ }^{b}$ Departamento de Ciências Básicas, Faculdade de Ciências Biológicas e da Saúde, Universidade Federal dos Vales do Jequitinhonha e Mucuri, 39100-000 Diamantina - MG, Brazil

${ }^{c}$ Centro de Pesquisas da Petrobras, Gerência de Biotecnologia e Tratamento Ambiental, Av. Jequitibá, 950, Ilha do Fundão, 21949-900 Rio de Janeiro - RJ, Brazil

\begin{abstract}
O processo de hidrólise do amido da torta de mamona por ácido e pela combinação de $\alpha$-amilase, glicoamilase e pululanase foi realizado, seguindo de etapa de fermentação. A hidrólise química resultou em $27.3 \mathrm{~g} \mathrm{~L}^{-1}$ de açúcares com $33.4 \%$ de eficiência de hidrólise. O hidrolisado obtido foi fermentado originando $11 \mathrm{~g} \mathrm{~L}^{-1}$ de etanol $\left(\mathrm{Y}_{\mathrm{P} / \mathrm{S}}=0.48 \mathrm{~g} \mathrm{~g}^{-1}\right)$. A melhor condição de hidrólise enzimática foi (por grama de torta de mamona): $200 \mu \mathrm{L}$ de $\alpha$-amilase, a $90{ }^{\circ} \mathrm{C} ; 200 \mu \mathrm{L}$ de glicoamilase e $100 \mu \mathrm{L}$ de pullulanase, ambas a $60{ }^{\circ} \mathrm{C}$, que resultou em $75 \mathrm{~g} \mathrm{~L}^{-1}$ de açúcares redutores totais, que corresponde a $91.4 \%$ de eficiência de hidrólise. Esses açúcares em seguida foram convertidos em $34.5 \mathrm{~g} \mathrm{~L}^{-1}$ etanol. O processo de hidrólise ácida foi capaz de promover a destoxificação da torta de mamona.
\end{abstract}

The starch hydrolysis process of Castor Bean Cake by (CBC) acid or enzymatic combination of alpha-amylase, glucoamylase and pullulanase was evaluated and followed by fermentation. The chemical hydrolysis resulted in $27.3 \mathrm{~g} \mathrm{~L}^{-1}$ of sugars with $33.4 \%$ of hydrolysis efficiency. The generated hydrolyzate was fermented yielding $11 \mathrm{~g} \mathrm{~L}^{-1}$ of ethanol $\left(\mathrm{Y}_{\mathrm{P} / \mathrm{S}}=0.48 \mathrm{~g} \mathrm{~g}^{-1}\right)$. The best enzymatic hydrolysis condition was as follows (per gram of $\mathrm{CBC}$ ): $200 \mu \mathrm{L}$ of $\alpha$-amylase, at $90{ }^{\circ} \mathrm{C} ; 200 \mu \mathrm{L}$ of glucoamylase and $100 \mu \mathrm{L}$ of pullulanase, both at $60{ }^{\circ} \mathrm{C}$, which yielded $75 \mathrm{~g} \mathrm{~L}^{-1}$ of total reducing sugars corresponding to $91.4 \%$ of hydrolysis efficiency. These sugars were subsequently converted to $34.5 \mathrm{~g} \mathrm{~L}^{-1}$ of ethanol. The acid hydrolysis process was also capable to allow the detoxification of the Castor Bean Cake.

Keywords: Castor Bean Cake, enzymatic hydrolysis, acid hydrolysis, bioethanol

\section{Introduction}

Castor Bean (Ricinus communis L.), also known as Castor oil Bean and wonder tree, is a member of Spurge family (Euforbiaceae) which is originated from tropical countries. The Castor Bean contains $40 \%$ of oil e $1-5 \%$ of a cytotoxic protein, named ricin, one of the most potent and deadly plant toxins known. ${ }^{1}$ Castor Bean cultivar was always considered as a subsistence agricultural activity experienced by few groups

*e-mail: nei@eq.ufrj.br of growers, mainly on the semi-arid region in Northeast of Brazil. On the other hand, efforts of the Brazilian government toward to develop this region, mainly by stimulating Castor Bean cultivation as potential source of development for biodiesel production, have changed this scenery. There are almost 4,000,000 ha in this region appropriated to be cultivated, which are capable to produce 1.5 tons of seed per ha. ${ }^{2}$ The oil extraction process of Castor Bean seeds for producing biodiesel and lubricants generates the Castor Bean Cake (CBC) as waste. This waste is highly-concentrated in protein and is produced at the ratio of 1.2 tons per ton of extracted oil, corresponding 
roughly to $55 \%$ of weight of seeds. ${ }^{3}$ On the other hand, the presence of anti-nutritional factors (ricine and ricinine) does not allow the utilization in natura of this waste as animal food. ${ }^{4,5}$ Additionally, since it contains high concentrations of starch, $\mathrm{CBC}$ is a potential feedstock for the production of bioethanol. ${ }^{3,6}$ Projections carried out by Freitas \& Fredo indicate that from 2006 onwards 20,000 tons of $\mathrm{CBC}$ will be available, due to the increasing biodiesel production. ${ }^{2}$

According to recent studies on transesterification of Castor Bean Oil to Biodiesel production, if $160 \mathrm{~L}$ of ethanol can be generated from 1 ton of CBC (produced by pressed seeds), the ethanol demand for the transesterification process of extracted oil into ethylic ester (Biodiesel) would be fullfiled and the process self-sufficient regarding the transesterification agent. ${ }^{7}$ Table 1 presents the main differences between the methylic and ethylic routes. Using different combinations of physical variables, as well as stoichiometric amounts of catalyst, alcohol and oil, it is possible to attain similar characteristics to the biodiesel produced by methylic route, since the comparative values are not quite different. The possibility of the ethanol use in the biodiesel production process has a great potential in the Brazilian industrial context, because of the high produced volumes of ethanol. The cost of each process depends on its variables and operational conditions.

Some environmental problems, like the greenhouse gas emissions and their consequences, show the importance of the biofuels on global warming attenuation. ${ }^{8,9}$ In this context, the availability of biomass and specific biotechnological resources place the ethanol and biodiesel as the most promising fuels. ${ }^{10-12}$ Current policies stimulate the development of these technologies. European countries are beginning to use the bioethanol/diesel and bioethanol/gasoline blends, as started by the directive 2003/2030 years. ${ }^{13}$

Connecting the need of treating the residue generated from Castor Bean Oil extraction to the potential of its Cake as a fermentable source of sugars, the present study aims at the development of enzymatic and chemical hydrolysis processes to promote the detoxification of the leftover Cake. Additionally, it is objective of investigation the production of ethanol by fermentation of the CBC hydrolysate to be used as a transesterification agent in biodiesel production, and thus establishing a self-sufficient and integrated biodieselbioethanol process, as illustrated in the Figure 1.

\section{Experimental}

\section{Castor Bean Cake}

Samples of Castor Bean Cake as a residue of biodiesel production process were harvested from the Biodiesel Pilot Plant of Petroleo Brasileiro SA (Petrobras). The solid residue was powdered and dried by 24 hours at $60{ }^{\circ} \mathrm{C}$ to eliminate moisture.

\section{Analysis of starch content from Castor Bean Cake}

Percentage of starch as dry weight was determined according to the enzymatic-colorimetric method for starch analysis of seeds that contains mixtures of amylose and amylopectin. ${ }^{14,15}$ Analyses were performed in triplicate.

Chemical hydrolysis of the starch from Castor Bean Cake

Chemical hydrolysis was carried out in autoclave (model 103; 4000W Fabbe-Primar ${ }^{\mathrm{TM}}$, Brazil) utilizing conical flasks of $250 \mathrm{~mL}$ containing $10 \mathrm{~g}$ of CBC (dry base) suspended in diluted sulfuric acid. Screening experimental design was created considering solid-liquid ratio 1:6, following the Factorial Fractional Design (FFD) $3^{k-1}$. Independent variables were: time, concentration of sulfuric acid and temperature. Dependent variable was concentration of sugars (Table 2).

Table 1. Biodiesel: comparison of the methylic and ethylic transesterification routes

\begin{tabular}{lll}
\hline Properties & Methylic Process & Ethylic Process \\
\hline Alcohol consumption $(\mathrm{kg})$ per $1000 \mathrm{~L}$ of biodiesel & 90 & 130 \\
Conversion (oil $\rightarrow$ biodiesel) & $97.5 \%$ & $94.3 \%$ \\
Glycerin produced & $0.87 \%$ & $1.40 \%$ \\
Variation power in relation to diesel & $-2.5 \%$ & $-4.0 \%$ \\
Variation consumption in relation to diesel & $10 \%$ & $12 \%$ \\
Average price of alcohol, US $\$ / \mathrm{m}^{3}$ & 200 & 370 \\
Reaction temperature & $60{ }^{\circ} \mathrm{C}$ & $85^{\circ} \mathrm{C}$ \\
Residence time & $45 \mathrm{~min}$ & $90 \mathrm{~min}$ \\
\hline
\end{tabular}

Source: Ma and Hanna. ${ }^{7}$ 


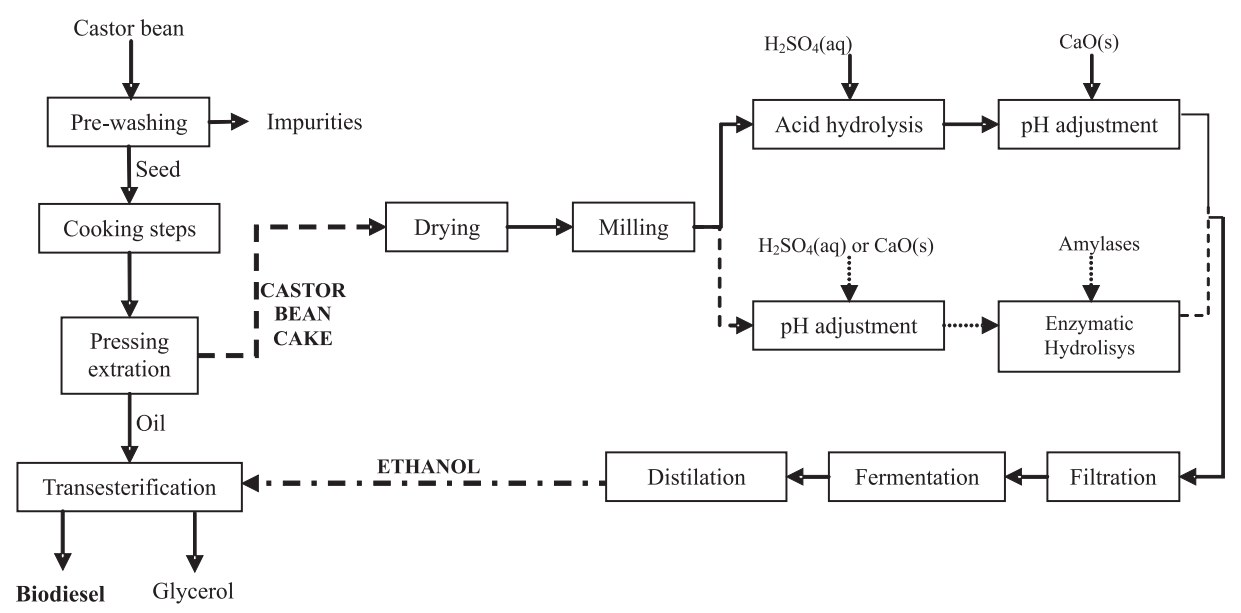

Figure 1. Summaries of the integration of the present proposal with biodiesel production within the context of residue/waste valorization.

Table 2. Variables and levels of Statistical Factorial Fractional Design (FFD) to evaluate chemical hydrolysis of Castor Bean Cake

\begin{tabular}{cccc}
\hline Variable & Level (-1) & $\begin{array}{c}\text { Center point } \\
(0)\end{array}$ & Level (+1) \\
\hline time / min & 20 & 30 & 40 \\
{$\left[\mathrm{H}_{2} \mathrm{SO}_{4}\right] /(\mathrm{mol} \mathrm{L}-1)$} & 0.25 & 0.50 & 0.75 \\
$\mathrm{~T} /{ }^{\circ} \mathrm{C}$ & 110 & 115 & 120 \\
Pressure & $0.5 \mathrm{~kg} \mathrm{~cm}^{-2}$ & $0.75 \mathrm{~kg} \mathrm{~cm}^{-2}$ & $1 \mathrm{~kg} \mathrm{~cm}^{-2}$ \\
\hline
\end{tabular}

The STATISTICA software 5.0 version (Statsoft Inc., Tulsa, UK) was utilized to generate and analyze the FFD. Model adjustment equation was confirmed by the correlation coefficient $\left(R^{2}\right)$ and statistical significance conditioned by the F-test. Significance for each parameter was depicted by Pareto diagram, with their correlations and curvatures.

\section{Enzymatic hydrolysis of the starch from Castor Bean Cake}

$\alpha$-Amylase (Termamyl Type L, $144 \mathrm{KNU} \mathrm{mL}^{-1}$ ), glucoamylase (AMG, $300 \mathrm{AGU} \mathrm{mL}^{-1}$ ) and pullulanase (Promozyme, $400 \mathrm{PUN} \mathrm{mL}^{-1}$ ), purchased from Novozymes Lantin American Ltd., were combined to promote CBC saccharification according to a full screening experimental design $3^{\mathrm{k}}$ (Table 3 ). Thirty independent runs were generated, three of them as center points. Hydrolytic assays were performed in a Dubnoff-type thermostatized bath, in $250 \mathrm{~mL}$ conical flasks containing $10 \mathrm{~g}$ of CBC. Experiments were run with a solid-liquid ratio of 1:6. Due to the specificity of each enzyme and the structure of starch from the seeds, $\alpha$-amylase $\left(90^{\circ} \mathrm{C}\right)$ was utilized in the first stage of hydrolysis. Thereafter, the temperature was lowered to $60^{\circ} \mathrm{C}$, for the action of glucoamylase and pullulanase, which were used combined. ${ }^{14}$
Table 3. Full Factorial Design for the action of amylolytic enzymes and their concentrations in the hydrolysis process

\begin{tabular}{cccc}
\hline Enzymes & Level (-) & $\begin{array}{c}\text { Center point } \\
(0)\end{array}$ & Level (+) \\
\hline Alfa-amylase $^{\mathrm{a}}$ & $0 \mathrm{KNU} \mathrm{g}^{-1}$ & $14.4 \mathrm{KNU} \mathrm{g}^{-1}$ & $28.8 \mathrm{KNU} \mathrm{g}^{-1}$ \\
Glucoamylase $^{\mathrm{b}}$ & $0 \mathrm{AGU} \mathrm{g}^{-1}$ & $30 \mathrm{AGU} \mathrm{g}^{-1}$ & $60 \mathrm{AGU} \mathrm{g}^{-1}$ \\
Pullulanase $^{\mathrm{c}}$ & $0 \mathrm{PUN} \mathrm{g}^{-1}$ & $20 \mathrm{PUN} \mathrm{g}^{-1}$ & $40 \mathrm{PUN} \mathrm{g}^{-1}$ \\
\hline
\end{tabular}

a KNU is defined as the amount of enzyme capable to promote rupture of 5.26 grams of starch per hour, in the conditions specified by the Novozymes stand method; ${ }^{\mathrm{b}} \mathrm{AGU}$ is defined as the amount of enzyme that hydrolyses $1 \mu \mathrm{mol}$ of maltose per minute under standard conditions; 'PUN is defined as the amount of enzyme that hydrolyses pullulan, releasing $1 \mu \mathrm{mol}$ glucose per minute under standard conditions (Novozymes Product Sheet, 2001-00746-03.pdf, 2001-12270-02.pdf e 2001-00464-40.pdf).

\section{Ethanol fermentation}

Fermentation media were obtained by centrifugation of the remaining solid residue of $\mathrm{CBC}$, after hydrolytic stage, followed by $\mathrm{pH}$ adjustment to 5.0 with calcium oxide of the liquid fraction. Fermentations were performed in an instrumented Bioreactor (Biostat ${ }^{\circledR}$ B.Braun Biotech International) with a working volume of $2 \mathrm{~L}$. The system was maintained at $30^{\circ} \mathrm{C}$ under stirring of $100 \mathrm{rpm}$ by eight hours. Saccharomyces cerevisiae was utilized as the fermentation agent with an initial concentration of $10 \mathrm{~g} \mathrm{~L}^{-1}$. Samples were harvested at 1 hour-interval, for analytical measurements.

\section{Analytical methods}

Ethanol was analyzed by HPLC (PUMP model 510, Waters) equipped with ionic exchange column Aminex ${ }^{\circledR}$ HPX-87P (Bio-Rad) and refraction index detector (model 2487, Waters). Standardized water MilliQ was used as mobile phase in a flow rate of $0.6 \mathrm{~mL} \mathrm{~min}^{-1}$. Sample volume 
was $5 \mu \mathrm{L}$. Oven and detector temperatures were $80^{\circ} \mathrm{C}$ and $40{ }^{\circ} \mathrm{C}$, respectively.

Total reducing sugars were analyzed by DNS method and glucose was quantified by the enzymatic-colorimetric method GOD-POD $\left(\right.$ CELM $\left.^{\circledR}\right){ }^{16}$

Biomass, after centrifugation and re-suspension in distilled water, was determined by absorbance measurement at $570 \mathrm{~nm}$ (Spectrumlab22PC spectrophotometer) which was further correlated to dry weight by a standard curve.

\section{Detoxification of the Castor Bean Cake}

$\mathrm{CBC}$ in natura, as well as the remaining solid residues from acid and enzymatic hydrolysis and the spend medium, resulting from the process of ethanol fermentation of both hydrolyzates, were evaluated for their possible cytotoxic effects. Three methodologies were utilized to estimate the toxicity in cultures of hepatocites of male mice Wistar and V79 cells of fibroblasts from lung of Chinese hamsters: analyses of extra cellular nucleic acid presence, mitochondrial decoloration of MTT and evaluation of lisossomes by coloration with neutral red. ${ }^{17-19}$ Results were expressed in terms of $\mathrm{IC}_{50}$ (inhibitory concentration which inhibits $50 \%$ of cell viability), in $\mathrm{mg} \mathrm{L}^{-1}$.

\section{Results and Discussion}

\section{Starch content from Castor Bean Cake}

Experiments for starch hydrolysis of Castor Bean Cake $(\mathrm{CBC})$ be it by acid or enzymatic procedures were proceeded by determination of starch concentration (percentage) in CBC, which resulted in $48 \pm 0.53$ (\%) in dry basis. This percentage, considering efficiency of $100 \%$ in the hydrolysis stage is equivalent to a potential amount of $53 \mathrm{~g}$ of glucose, which would result in $25.3 \mathrm{~g}$ of ethanol for each $100 \mathrm{~g}$ of Cake. These values were considered as reference for calculating the process efficiency.

\section{Acid hydrolysis from Castor Bean Cake}

Assays in duplicate of the acid hydrolysis of the CBC through experimental planning $3^{3-1}$ ( 3 variables and 3 levels) are showed in Table 4. According to the variances analysis, the values of $R^{2}(0.985)$, pure error (2.457) and lack of fit (0.265), shows that the model is in accordance with the experimental datas. Analysis of the response-factor (concentration of reducing sugars) gives emphasis to experimental condition number 6, with the lowest acid concentration and the highest temperature, as the most efficient. Under these conditions $30 \mathrm{~g} \mathrm{~L}^{-1}$ of reducing sugars were obtained, corresponding an to acid hydrolysis efficiency $\left(\mathrm{Ef}_{\mathrm{HA}}\right)$ of $33.5 \%$. Statistical treatment of the results, by Statistica software, generated predicted values with low residues (Table 4). Pareto diagram analysis (Figure 2) showed that, variables, 1 (time) and 2 (Temperature) presented significant positive linear effects on $\mathrm{CBC}$ hydrolysis. On the other hand, variable $3 \mathrm{(H}_{2} \mathrm{SO}_{4}$ concentration), displayed negative effect (-7.64\%), suggesting that the acid hydrolysis prevails at lower concentrations of acid. This statistical results does not corroborate to expected effect of acid concentration in the hydrolytic process. The hydrolysis efficiency is reduced when the acid concentration is higher than $0.25 \mathrm{~mol} \mathrm{~L}^{-1}$. However, the explanation of this antagonic effect may be due to the possible decomposition of sugars to furfural and hydroxy-methyl-furfural under extreme conditions of temperature and $\mathrm{pH}$, that turn the system more oxidizing. ${ }^{20}$ This hypothesis also finds support by the negative effect evidenced in the interactions of variables 1 (time) and 2 (Temperature). Recent researches relate that increased yields of chemical hydrolysis of biomass are achieved when conventional hydrolysis accompanies thermal processing. However, ultra-high-pressure has the highest cost. $^{21}$

Table 4. Chemical hydrolysis of Castor Bean Cake with a solid-liquid ratio of 1:6, according to the experimental design shown in Table 2

\begin{tabular}{|c|c|c|c|c|c|}
\hline Experiment & time / min & Temperature $/{ }^{\circ} \mathrm{C}$ & {$\left[\mathrm{H}_{2} \mathrm{SO}_{4}\right] /\left(\mathrm{mol} \mathrm{L}^{-1}\right)$} & Sugars / $\left(\mathrm{g} \mathrm{L}^{-1}\right)$ & Sugars / $\left(\mathrm{g} \mathrm{L}^{-1}\right)$ (predict) \\
\hline 1 & 15 & 110 & 0.25 & $11.0 \pm 1$ & $11.0 \pm 0.7$ \\
\hline 2 & 15 & 115 & 0.75 & $12.9 \pm 0.8$ & $15.8 \pm 2.8$ \\
\hline 3 & 15 & 120 & 0.5 & $22.0 \pm 0.4$ & $21.7 \pm 2.0$ \\
\hline 4 & 30 & 110 & 0.75 & $24.6 \pm 0.8$ & $21.7 \pm 2.2$ \\
\hline 5 & 30 & 115 & 0.5 & $21.8 \pm 0.6$ & $21.8 \pm 0.4$ \\
\hline 6 & 30 & 120 & 0.25 & $27.2 \pm 0.1$ & $30.1 \pm 2.9$ \\
\hline 7 & 45 & 110 & 0.5 & $12.1 \pm 0.8$ & $19.9 \pm 3.3$ \\
\hline 8 & 45 & 115 & 0.25 & $26.0 \pm 1$ & $25.1 \pm 2.1$ \\
\hline 9 & 45 & 120 & 0.75 & $26.7 \pm 0.4$ & $26.7 \pm 0.3$ \\
\hline
\end{tabular}




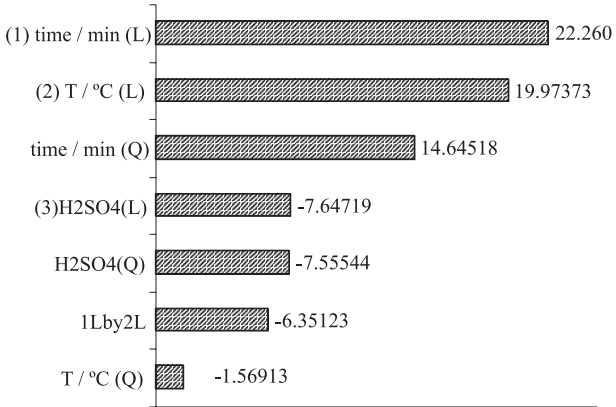

Figure 2. Pareto chart of starch acid hydrolysis of the $\mathrm{CBC}$, considering minimal confidence range of $95 \%$.

Table 5. Action of amylases and their concentrations following full factorial design (Table 3)

\begin{tabular}{|c|c|c|c|c|}
\hline Experiment & $\begin{array}{c}\alpha \text {-Amylase/ } \\
\mu \mathrm{L}\end{array}$ & $\begin{array}{c}\text { Pullulanase/ } \\
\mu \mathrm{L}\end{array}$ & $\begin{array}{c}\text { Glucoamylase/ } \\
\mu \mathrm{L}\end{array}$ & $\begin{array}{c}\text { Sugars/ } \\
\left(\mathrm{g} \mathrm{L}^{-1}\right)\end{array}$ \\
\hline 1 & 0 & 0 & 0 & $2.3 \pm 0.2$ \\
\hline 2 & 0 & 0 & 100 & $35.6 \pm 1.1$ \\
\hline 3 & 0 & 0 & 200 & $31.5 \pm 0.8$ \\
\hline 4 & 0 & 50 & 0 & $23.2 \pm 2.1$ \\
\hline 5 & 0 & 50 & 100 & $26.5 \pm 1.4$ \\
\hline 6 & 0 & 50 & 200 & $33.1 \pm 3.0$ \\
\hline 7 & 0 & 100 & 0 & $19.0 \pm 1.2$ \\
\hline 8 & 0 & 100 & 100 & $24.0 \pm 0.2$ \\
\hline 9 & 0 & 100 & 200 & $47.2 \pm 2.6$ \\
\hline 10 & 100 & 0 & 0 & $21.5 \pm 0.7$ \\
\hline 11 & 100 & 0 & 100 & $30.6 \pm 0.7$ \\
\hline 12 & 100 & 0 & 200 & $47.2 \pm 0.3$ \\
\hline 13 & 100 & 50 & 0 & $24.8 \pm 0.5$ \\
\hline 14 & 100 & 50 & 100 & $39.8 \pm 1.5$ \\
\hline 15 & 100 & 50 & 200 & $63.7 \pm 2.1$ \\
\hline 16 & 100 & 100 & 0 & $25.7 \pm 1.2$ \\
\hline 17 & 100 & 100 & 100 & $45.5 \pm 3.1$ \\
\hline 18 & 100 & 100 & 200 & $43.9 \pm 2.9$ \\
\hline 19 & 200 & 0 & 0 & $27.3 \pm 0.1$ \\
\hline 20 & 200 & 0 & 100 & $37.3 \pm 0.4$ \\
\hline 21 & 200 & 0 & 200 & $54.6 \pm 2.2$ \\
\hline 22 & 200 & 50 & 0 & $29.8 \pm 1.0$ \\
\hline 23 & 200 & 50 & 100 & $40.6 \pm 2.3$ \\
\hline 24 & 200 & 50 & 200 & $51.3 \pm 3.4$ \\
\hline 25 & 200 & 100 & 0 & $26.5 \pm 0.4$ \\
\hline 26 & 200 & 100 & 100 & $55.5 \pm 0.7$ \\
\hline 27 & 200 & 100 & 200 & $74.5 \pm 1.1$ \\
\hline $28(\mathrm{CP})^{*}$ & 150 & 50 & 100 & $44.7 \pm 0.8$ \\
\hline $29(\mathrm{CP})^{*}$ & 150 & 50 & 100 & $41.4 \pm 1.1$ \\
\hline $30(\mathrm{CP})^{*}$ & 150 & 50 & 100 & $44.7 \pm 0.3$ \\
\hline
\end{tabular}

*Center Points.

\section{Enzymatic hydrolysis from Castor Bean Cake}

The enzymatic hydrolysis of starch from $\mathrm{CBC}$ was initiated with the use of $\alpha$-amylase enzyme (-1,4-glucan-4glucanohydrolase) at $90^{\circ} \mathrm{C}$ to liquefy starch. On the sequence, glucoamylase (amyloglucosidase or 1,4-glucanohydrolase) acting on $-1,4$ bounds from the reducing polysaccharide extremities releasing glucose. Glucoamylase was combined with pullulanase, which acts with high specificity on the glycoside $-1,6$ bounds in amylopectin, reducing the remaining oligosaccharides, and therefore contributing for the release of fermentable sugars..$^{22,23}$

Results of the screening experimental design combining three kinds of amylases had as the response-factor the concentration of reducing sugars. These experiments were carried out utilizing 1:6 solid-liquid ratio in order to improve the enzyme action, resulting in a better mass transfer in this heterogeneous media. Results are shown in Table 5.

Experiment 27 (Table 5), performed with the highest concentrations of enzymes, presented the best response among the evaluated concentration ( $74.5 \mathrm{~g}$ of reducing sugar), leading to a starch hydrolysis efficiency of $91.4 \%$. This result indicates that the process is efficient, becoming unnecessary the evaluation of others levels of enzymatic concentration. Combined use of pullulanase, $\alpha$-amylase and glucoamylase (experiment 27) when compared to the use of only $\alpha$-amylase and glucoamylase (experiment 21) resulted in an increase of $26.6 \%$ on the concentration of reducing sugars. This is surely due to the specific action of pullulanase on the residual $-1,6$ bound, increasing the rate of free glucose production. Pareto chart (Figure 3) evidenced the statistical significance of linear effects of the three amylases evaluated in the hydrolysis process and the combined effect of $\alpha$-amylase and glucoamylase action. ${ }^{14}$

The best conditions for starch saccharification of CBC indicated by the experimental design analysis of the acid hydrolysis (experiment 6 , Table 4 ) and enzymatic

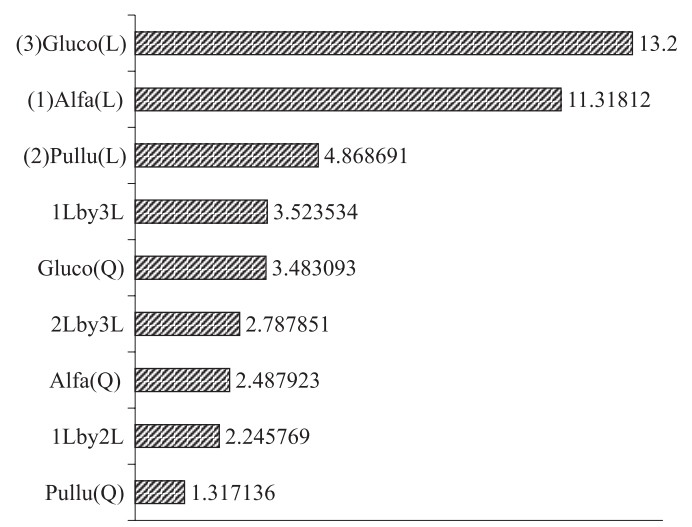

Figure 3. Pareto chart amylases effect at the hydrolysis of Castor Bean Cake. 
hydrolysis (experiment 27, Table 5) were used to prepare the fermentation media for ethanol production.

\section{Ethanol fermentation of the hydrolysates from Castor Bean Cake}

The CBC acid hydrolyzate was inoculated with a cell concentration of $9.5 \mathrm{~g}$ (d.w.) $\mathrm{L}^{-1}$, and the fermentation was operated batchwise (Figure 4 ). The process lasted $8 \mathrm{~h}$, when the ethanol concentration reached $11 \mathrm{~g} \mathrm{~L}^{-1}$, corresponding to a yield of product on substrate consumed of $0.480 \mathrm{~g} \mathrm{~g}^{-1}$ and a volumetric productivity of $1.38 \mathrm{~g} \mathrm{~L}^{-1} \mathrm{~h}^{-1}$. Considering the acid hydrolysis efficiency (33.5\%) and the response variables of ethanol fermentation, we can estimate a ratio of 108 liters of anhydride ethanol per ton of CBC (dry base), which would supply $83 \%$ of the ethanol demand for biodiesel production from Castor Bean oil.

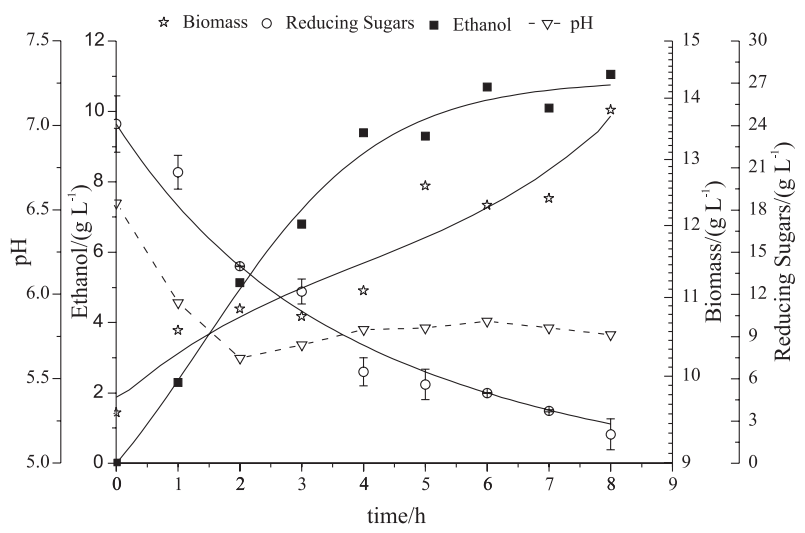

Figure 4. Ethanol fermentation of the acid hydrolyzate of Castor Bean Cake.

Similarly, the CBC enzymatic hydrolyzate was fermented batchwise for $10 \mathrm{~h}$, and the main process variables (ethanol, sugar and cell concentrations, as well as $\mathrm{pH}$ ) were monitored throughout the fermentation (Figure 5). After $5 \mathrm{~h}$ of fermentation, the ethanol concentration reached its maximum value $\left(34.5 \mathrm{~g} \mathrm{~L}^{-1}\right)$, corresponding to a yield of product on substrate consumed of $0.465 \mathrm{~g} \mathrm{~g}^{-1}$ and a volumetric productivity of $6.98 \mathrm{~g} \mathrm{~L}^{-1} \mathrm{~h}^{-1}$.

Then again, considering the enzymatic hydrolysis efficiency of $91.4 \%$, it is possible to estimate that 270 liters of ethanol could be produced from 1 ton of CBC. A mass balance for the transesterification reaction allows to figure out that the process has the potential to supply a double of the ethanol demanded for biodiesel production from Castor Bean oil.

\section{Analysis from detoxification of the Castor Bean Cake}

These results point out for the starch enzymatic

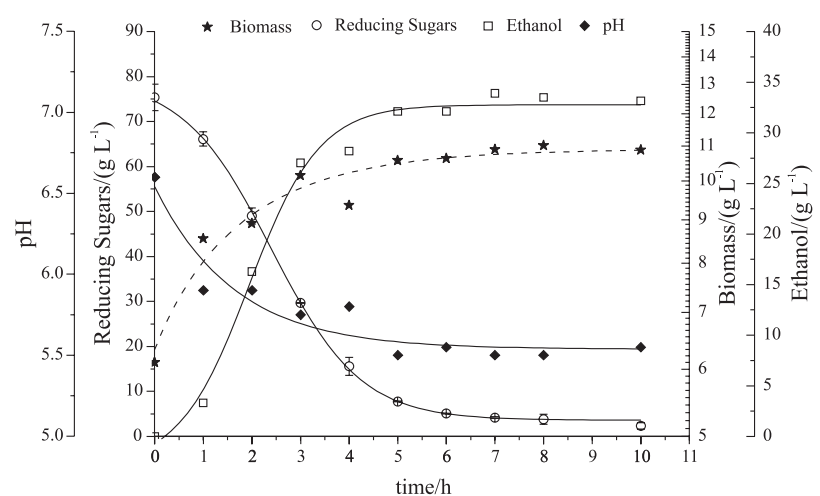

Figure 5. Ethanol fermentation of the enzymatic hydrolyzate Castor Bean Cake.

hydrolysis of CBC. Furthermore, waste residues of hydrolytic and fermentative were also analyzed as far as their effectiveness on detoxification (Table 6). The results show the inhibitory concentration of $50 \%$ for cell population to different viability markers (mitochondria, lisossomes and nucleic acids) obtained in assays with hepatocites from male Wistar mice. Table 7 present results of cytotoxicity $\left(\mathrm{IC}_{50}\right.$ in $\mathrm{mg} \mathrm{L}^{-1}$ ) obtained in assays with V79 cells.

Table 6. Cytotoxic effect $\left(\mathrm{IC}_{50}\right)$ in hepatocites utilizing residues from hydrolysis and fermentation of Castor Bean Cake

\begin{tabular}{cccccc}
\hline Tests & $\begin{array}{c}\text { Cake/ } \\
\left(\mathrm{mg} \mathrm{L}^{-1}\right)\end{array}$ & $\begin{array}{c}\mathrm{HA} / \\
\left(\mathrm{mg} \mathrm{L}^{-1}\right)\end{array}$ & $\begin{array}{c}\mathrm{FA} / \\
\left(\mathrm{mg} \mathrm{L}^{-1}\right)\end{array}$ & $\begin{array}{c}\mathrm{HE} / \\
\left(\mathrm{mg} \mathrm{L}^{-1}\right)\end{array}$ & $\begin{array}{c}\mathrm{FE} / \\
\left(\mathrm{mg} \mathrm{L}^{-1}\right)\end{array}$ \\
\hline $\begin{array}{c}\text { Mitocondries } \\
(\mathrm{MTT})\end{array}$ & 100 & 2980 & 5000 & 360 & 1260 \\
$\begin{array}{c}\text { Lisossomes } \\
(\mathrm{VN})\end{array}$ & 170 & 4950 & 1630 & 170 & 2070 \\
$\begin{array}{c}\text { Nucleic } \\
\text { Acids }\end{array}$ & 320 & 4640 & 5000 & 510 & 5000 \\
\hline
\end{tabular}

HA: Solid residue from acid hydrolysis, FA: waste of fermented acid hydrolysate, HE: residue from enzymatic hydrolysis, FE: waste of fermented enzymatic hydrolyzate. IC $_{50}$ : Inhibitory concentration which inhibits $50 \%$ of cell viability.

Table 7. Cytotoxic effect $\left(\mathrm{IC}_{50}\right)$ in V79 cells utilizing residues from hydrolysis and fermentation of Castor Bean Cake

\begin{tabular}{cccccc}
\hline Tests & $\begin{array}{c}\text { Cake/ } \\
\left(\mathrm{mg} \mathrm{L}^{-1}\right)\end{array}$ & $\begin{array}{c}\mathrm{HA} / \\
\left(\mathrm{mg} \mathrm{L}^{-1}\right)\end{array}$ & $\begin{array}{c}\mathrm{FA} / \\
\left(\mathrm{mg} \mathrm{L}^{-1}\right)\end{array}$ & $\begin{array}{c}\mathrm{HE} / \\
\left(\mathrm{mg} \mathrm{L}^{-1}\right)\end{array}$ & $\begin{array}{c}\mathrm{FE} / \\
\left(\mathrm{mg} \mathrm{L}^{-1}\right)\end{array}$ \\
\hline $\begin{array}{c}\text { Mitocondries } \\
(\text { MTT })\end{array}$ & 300 & 2200 & 4660 & 490 & 1950 \\
$\begin{array}{c}\text { Lisossomes } \\
(\mathrm{VN})\end{array}$ & 350 & 4340 & 2340 & 700 & 3970 \\
$\begin{array}{c}\text { Nucleic } \\
\text { Acids }\end{array}$ & 640 & 4670 & 5000 & 590 & 5000
\end{tabular}

HA: Residue from acid hydrolysis, FA: waste of fermented acid hydrolysate, HE: residue from enzymatic hydrolysis, FE: waste of fermented enzymatic hydrolysate. $\mathrm{IC}_{50}$ : Inhibitory concentration which inhibits $50 \%$ of cell viability. 
The residue characterization obtained after hydrolysis was done in the Institute of Food Technology of Sao Paulo State, and the results indicate absence of starch in the solid residue of the enzymatic process. Both the hydrolisates (acid and enzymatic) have the same composition (mg per $100 \mathrm{~g}$ ): lipids 3,200; protein, 23,100; fiber, 23,200; calcium, 396; phosphorous, 603; magnesium, 269; potassium, 290 and sodium, 583.

As expected, in both cytotoxicity tests, $\mathrm{CBC}$ in nature presented high cytotoxic effect, with dosage $\left(\mathrm{IC}_{50}\right)$ lower than standard value of $640 \mathrm{mg} \mathrm{L}^{-1} .^{24}$ The solid residue derived from chemical hydrolysis (HA), as well as the stillage generated from distillation of the fermented medium (FA), displayed cytotoxic effects in concentrations much higher than $\mathrm{IC}_{50}$ obtained with the $\mathrm{CBC}$ in natura. On the contrary, the enzymatic hydrolysis (HE) was not capable to promote significant detoxification of $\mathrm{CBC}$ in nature, (lower values of $\mathrm{IC}_{50}$ ). The same did not occur with the stillage (FE) from the fermentation of the enzymatic hydrolysate. The fermentation stage and the subsequent distillation probably generate a stillage with low cytotoxicity, presenting the highest values of $\mathrm{IC}_{50}$ at the same order of magnitude of the values obtained with the solid residue from the chemical hydrolysis (HA).

\section{Conclusions}

Acid hydrolysis process of Castor Bean Cake, at optimal condition, occurred under technically viable levels, $\left(0.25 \mathrm{~mol} \mathrm{~L}^{-1}\right.$ of $\mathrm{H}_{2} \mathrm{SO}_{4}, 120{ }^{\circ} \mathrm{C}$ and 30 minutes $)$. Additionally, the chemical process was able to promote significant toxicity reduction of $\mathrm{CBC}$. However, acid hydrolysis showed to be limited, resulting in a low hydrolysis efficiency $\left(\mathrm{Ef}_{\mathrm{HA}}=33.5 \%\right)$.

$\mathrm{CBC}$ enzymatic hydrolysis process pointed out as a promising procedure, providing that an optimum combination of $\alpha$-amylase, glucoamylase and pullulanase is used. At the best conversion condition, CBC starch was hydrolyzed with $91.4 \%$ of efficiency. Taking into account the saccharification and fermentation efficiencies, it is possible to forecast an ethanol production corresponding to $270 \mathrm{~L}$ per ton of processed Cake (dry bases). This value is 2 fold higher than the demanded ethanol volume in the transesterification process of extracted oil from 2 ton of Castor Bean seed, according to the process of biodiesel production developed in a semi-industrial scale in the Brazilian Oil Research Center (Petrobrás) (data not published).

Considering the increasing generation of residue associated to production of oil from Castor Bean seeds for biodiesel production, the utilization of $\mathrm{CBC}$, associated to co-generation of ethanol, could be integrated to the transesterification process, reducing costs and giving solution to destination of Castor Bean seed residue. The cost reduction and the scale up are the main objectives of the new process development in this area, according to recent works. ${ }^{25}$

\section{Acknowledgments}

Authors would like to acknowledge the Conselho Nacional de Desenvolvimento Científico e Tecnológico (CNPq), Centro de Pesquisas da Petrobras (CENPES) and the Post-graduation Program on Technology of Chemical and Biochemical Processes of the School of Chemistry of the Universidade Federal do Rio de Janeiro (Brazil).

\section{References}

1. Aslani, M. R.; Malekib, M.; Mohria, M.; Sharifia, K.; NajjarNezhada, V.; Afshari, E.; Toxicon 2007, 49, 400.

2. Freitas, S. M.; Fredo, C. E.; Inform. Econ. 2005, 35, 1.

3. Azevedo, D. M. P.; Lima, E. F. In O Agronegócio da Mamona no Brasil; Embrapa: Campina Grande-Paraíba, 2001, ch.2.

4. Frigerio, L.; Jolliffe, N. A.; Felipe, D. H.; Paris, N.; Neuhaus, J. M.; Lord, J. M.; Ceriotti, A.; Roberts, L. M.; Plant Physiol. 2001, 126, 167.

5. Bashir, M. E.; Hubatsch, I.; Leinenbach, H. P.; Zeppezauer, M.; Panzani, R. C.; Hussein, I. H.; Int. Arch. Allergy Immunol. 1998, 115, 73 .

6. Silva, J. G.; Machado, O. L.; Izumi, C.; Padovan, J. C.; Chait, B. T.; Mirza, U. A.; Arch. Biochem. Biophys. 1996, 336, 10.

7. Ma, F.; Hanna, M. A.; Bioresour. Technol. 1999, 15, 1.

8. Blottnitz, H. V.; Curran, M. A.; J. Cleaner Prod. 2007, 15, 607.

9. Wesseler, J.; Energy Policy 2007, 35, 1414.

10. Wright, L.; Biom. Bioener. 2006, 30, 706.

11. Demirbas, A.; Prog. Energy Combust. Sci. 2007, 33, 1.

12. Hahn-Hagerdal, B.; Galbe, M.; Gorwa-Graunslund, M. F.; Lidén, G.; Zacchi, G.; Trends Biotechnol. 2006, 24, 549.

13. Lapuerta, M.; Armas, O., Garcia-Contreras, R.; Fuel 2007, 86, 1351.

14. Gupta, M. N.; Roy, I.; Enzyme Microb. Technol. 2004, 34, 26.

15. Quigley, M. E.; Hudson, G. F.; Englyst, H. N.; Food Chem. 1999, 65, 381.

16. Miller, G. L.; Anal. Chem. 1959, 31, 426.

17. Cingi, M. R.; De Angelis, I.; Fortunati, E.; Reggiani, D.; Bianchi, V.; Tiozzo, R.; Zucco, F.; Toxicol. In Vitro 1991, 5, 119.

18. Freshney, R. I.; J. Immunol. Methods 1986, 89, 271.

19. Borenfreund, E.; Puerner, J. A.; J. Tiss. Cult. Met. 1984, 9, 7.

20. Ramos, L. P.; Quim. Nova 2003, 26, 863.

21. Lee, J.; Choi, H.; Kim, B.; Chung, M.; Kim, D.; Choi, S. M.; Food Sci.Technol. 2006, 39, 1125. 
22. Crabb, W. D.; Shetty, J. K.; Curr. Opin. Microbiol. 1999, 1, 252.

23. Ara, K.; Saeki, K.; Igarashi, K.; Takaiwa, M.; Uemura, T.; Hagihara, H.; Biochim. Biophys. Acta 1995, 1243, 315.
24. Fortunati, E.; Debetto, P.; Borella, S.; Bianchi, V.; Toxicol. in Vitro 1993, 7, 511.

25. Massarrat, M.; Scient. Am. 2007, 57, 73.

Received: February 12, 2007 Web Release Date: February 8, 2008 